\title{
Rhodium-Catalyzed Enantioselective Hydroamination of Allenes
}

\section{Category}

Metal-Catalyzed Asymmetric

Synthesis and

Stereoselective

Reactions

\section{Key words}

rhodium

hydroamination

allenes
Selected examples:<smiles>C=CC(Nc1ccccc1)C1CCCCC1</smiles>
$89 \%$ ee<smiles>C=CC(O)Nc1ccc(OC)cc1</smiles>

$78 \%$ yield
$80 \%$ ee

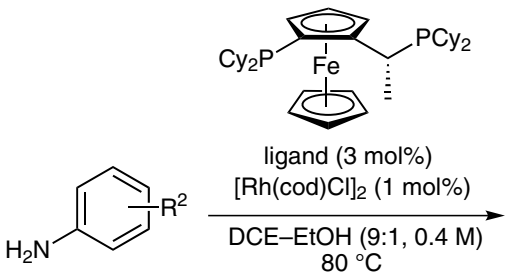<smiles>[R]C(C=C)Nc1ccccc1</smiles>

Significance: Despite the versatility of $\alpha$-chiral allylic amines, synthetic methods to access them have been underdeveloped. The authors reported the first example of the enantioselective intermolecular hydroamination of mono-substituted allenes.<smiles>C=CC(Nc1ccc(O)cc1)C1CCCCC1</smiles><smiles>C=CC(Nc1ccc2[nH]ccc2c1)C1CCCCC1</smiles><smiles>C=CC(CCc1ccccc1)Nc1ccc(OC)cc1</smiles><smiles>C=CC(CCOC(C)(C)C)Nc1ccc(OC)cc1</smiles><smiles>C=CC(CCOCC)Nc1ccc(OC)cc1</smiles>

Proposed mechanism:<smiles>[R]C(N)/C(C=O)=C/O</smiles>
$[\mathrm{Rh}]$ $\operatorname{ArNH}_{2}\left(\mathrm{ArND}_{2}\right)$

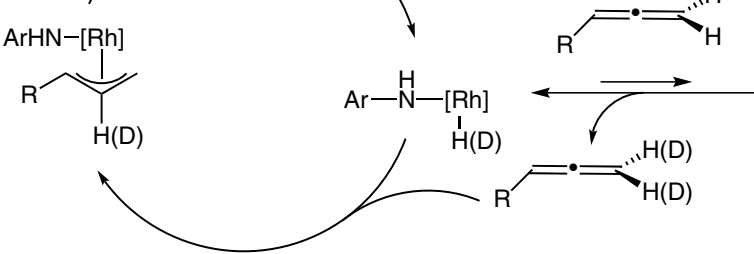

ArHN-[Rh]<smiles>C/C=C\CC</smiles>

Comment: A variety of substituted anilines, even bearing unprotected alcohol and indole moieties, were employed to give good yields and high enantioselectivities. Further mechanistic study is desirable to explain the regioselectivity of the hydrometalation step.

SYNFACTS Contributors: Hisashi Yamamoto, Susumu Oda 